\title{
REPENSANDO OS ESTUDOS CRÍTICOS EM ADMINISTRAÇÃO
}

\author{
Por Ana Paula Paes de Paula \\ Professora Titular do Programa de Mestrado Acadêmico em Administração da UNIP. \\ Pós-doutoranda em Administração de Empresas pela FGV-EAESP. \\ E-mail: appaula@uol.com.br
}

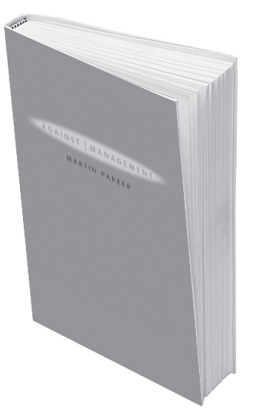

\section{AGAINST MANAGEMENT: ORGANIZATION IN THE AGE OF MANAGERIALISM}

De Martin Parker

Cambridge: Polity, 2002. 256 p.
Neste livro, Martin Parker oferece-nos um balanço da crítica do gerencialismo, apontando os limites e desafios que circundam os acadêmicos da área. O ponto de partida de sua análise é a inter-relação do management com o liberalismo de mercado. Seu argumento é que o management - que pode ser interpretado como o processo ou ato de gerenciar, ou a disciplina acadêmica dirigida para a Administração - passou a ocupar um lugar central nas sociedades industriais avançadas, sendo visto como uma precondição para o progresso social e o crescimento econômico. Nesse contexto, o management costuma ser utilizado como uma tecnologia de controle que se sustenta na celebração da classe gerencial, na aplicação de sua linguagem nas áreas informais da vida e na disseminação de formas particulares de expertise pelas escolas de Administração.

Parker procura persuadir o leitor de que o management está sendo crescentemente questionado, demons- trando que há várias manifestações de insatisfação com suas atividades. Para isso, aborda em primeiro lugar a crítica da racionalização burocrática e, em seguida, examina sua tradução no antigerencialismo contemporâneo, analisando o movimento da ética nos negócios, o movimento dos estudos críticos em Administração, as representações culturais contra o management e os movimentos anticorporativos das últimas décadas.

Sua intenção é se posicionar contra uma noção muito particular de management que está imbricada com uma ampla variedade de problemas políticos e éticos que, por sua vez, limitam nossa capacidade de imaginar formas alternativas de organização. Para o autor, a hegemonia do gerencialismo está ameaçada, mas isso não justifica um otimismo ideológico: é preciso examinar com cuidado as manifestações de crítica, realizando uma análise exaustiva das mesmas.

No que se refere à crítica da racionalização burocrática, Parker apresen- ta a oposição entre dois livros fundamentais para todos aqueles que se dedicam a essa discussão: The mcdonaldization of society (Thousand Oaks, CA: Pine Forge, 1996), de Ritzer e In praise of bureaucracy (London: Sage, 2000), de Du Gay. O autor compartilha das críticas de Du Gay ao trabalho de Ritzer, que poderia ter ido mais longe na avaliação da "mcdonaldização", uma vez que ele aborda apenas o fenômeno da racionalização e não discute a atuação do McDonald's enquanto ícone do liberalismo de mercado.

Para Parker, embora as ditas formas pós-burocráticas e pós-modernas de organização sejam criticadas por marxistas, weberianos e foucaultianos, as mesmas encerram características que deveriam ser analisadas em outra perspectiva. Uma delas é a idéia de comprometimento presente em algumas formulações de trabalho e organização, pois estas contêm noções de cidadania corporativa e comunitarismo organizacional que são 
potencialmente interessantes, na medida em que geram uma nova consciência de direitos e responsabilidades que pode levar os funcionários a questionarem a lógica do management. Apesar disso, ele reconhece que sempre há a possibilidade de cooptação e que devemos ser cautelosos em assumir que o mundo do trabalho realmente possa ser descrito dessa forma.

Depois de avaliar a crítica da racionalização burocrática, Parker examina as manifestações contemporâneas da crítica ao gerencialismo. Em primeiro lugar, analisa o movimento da ética nos negócios, retomando sua história e identificando suas contribuições para a mudança de atitude em relação à responsabilidade social. No entanto, reconhece que esse movimento pode ser visto como uma colonização gerencial dos projetos emancipatórios e enfatiza que ele está mais voltado para sua própria constituição, pois não está em seu escopo questionar as deficiências políticas do management e das organizações.

Em seguida, realiza um balanço dos estudos críticos em Administração, demonstrando que este é um movimento ambicioso mas, ao mesmo tempo, contraditório e de alcance limitado, uma vez que a crítica é realizada por profissionais das escolas de Administração e em geral se restringe às fronteiras do trabalho acadêmico. Além disso, esses estudos têm uma tendência a enfatizar sua novidade e relevância, não dando a devida importância à literatura em sociologia das organizações que os precede. Por outro lado, os sociólogos continuam pesquisando variadas formas clássicas de desigualdade, mas parecem relativamente desinteressados em relação às questões organizacionais. Em outras palavras, não se explora a conexão entre os estudos críticos e a sociologia das organizações.

Parker também afirma que no Rei- no Unido os estudos críticos em Administração representam uma forma muito particular de crítica pós-estruturalista que tende a excluir importantes elaborações neomarxistas. Alerta, assim, para o fato de esses estudos serem diferentes em outras partes do mundo, abrindo um espaço para pensarmos como se caracterizam os trabalhos realizados em outros países. $\mathrm{O}$ autor ainda questiona a definição de estudos críticos baseada na intenção não performática, ou seja, em seu afastamento da construção de instrumentos de eficiência gerencial, na desnaturalização de idéias e conceitos que são tomados como certos e na reflexividade, que consiste na problematização de suas próprias proposições. Em sua visão, uma vez que a crítica segundo a qual o gerencialismo é patriarcal e cúmplice da ordem imperial costuma ficar no nível da retórica, algumas práticas de mudança, ainda que cooptadas, estão sortindo mais resultado do que os estudos críticos.

Após essa análise dos estudos críticos, Parker argumenta que muitos livros e filmes contemporâneos contêm representações implícitas ou explícitas sobre o management que refletem um considerável grau de ambivalência. Pode parecer paradoxal, pois estes também são produzidos por grandes corporações. Nesse caso, porém, a indústria do entretenimento não está muito interessada no conteúdo do produto, mas no impacto que ele gera no mercado. O autor, no entanto, reconhece que a visão crítica sobre o gerencialismo nos filmes e livros não é nova, embora sua ressurgência como uma espécie de narrativa do senso comum seja indicativa de mudanças no clima político.

Entre tais mudanças, Parker aponta a emergência de uma contracultura corporativa que ataca o management por meio de movimentos sociais, como as lutas contra o ajuste estrutural, pela paz, pelos direitos humanos e pela reforma agrária e os movimentos anticorporações, ciber-libertários, ambientalistas, socialistas e anarquistas. $\mathrm{O}$ autor então aponta que esses movimentos transcendem as discussões e ações das outras formas de resistências organizadas ao management, devendo, portanto, ser analisados com maior cuidado.

Parker encerra o livro levantando uma questão que pretende explorar mais em outro trabalho: as formas alternativas de organização, como as comunidades e as cooperativas. É preciso notar que o gerencialismo pode ser visto como um elemento "de fachada" para exercer uma determinada forma de dominação, podendo emprestar o discurso da burocracia, da comunidade, da cidadania e da cultura, mas em todos os casos encerra formas de engenharia social que são essencialmente gerenciais. Dessa forma, ser contra o management é uma maneira de tentar imaginar ou relembrar alternativas a ele.

"Against management" é um livro que merece atenção, pois oferece uma síntese rigorosa e provocativa das manifestações de crítica ao gerencialismo realizada por um especialista na área que não se furta a fazer autocrítica. Além disso, estimula a pensar sobre a natureza dos estudos críticos em Administração no Brasil, principalmente de autores como Maurício Tragtenberg, Alberto Guerreiro Ramos e Fernando C. Prestes Motta. Aliás, para aqueles que não estão dispostos a esperar pelo próximo livro de Martin Parker, recomenda-se a leitura de A nova ciência das organizações (Rio de Janeiro: FGV, 1981) de Guerreiro Ramos, pois este se volta justamente para a análise de formas não gerencialistas de organização. Certamente o leitor vai se impressionar com a atualidade e o vanguardismo de suas proposições. 